\title{
COMPARATIVE ANALYSIS OF THE CRITERION FOR LAND RECLAMATION OF ANIZOTROPICAL-HALOMORPHIC SOILS
}

\section{KOMPARATIVNA ANALIZA KRITERIJUMA KOMPLEKSNIH MELIORACIJA ANIZOTROPNIH-HALOMORFNIH ZEMLJIŠTA}

\section{Branislav Žeželj ${ }^{1}$, Stanislav Glumac ${ }^{2}$, Zdravko Hojka ${ }^{3}$}

1 “Meling” Ltd. Comp. Owner-Manager, Goce Delceva no.13, 11080, Belgrade, Serbia

${ }^{2}$ Megatrend University, Faculty of Business studies, Goce Delceva no.8, 11080, Belgrade, Serbia

${ }^{3}$ Megatrend University, Faculty for Bio farming, M.Tito no.39, 24300 Backa Topola, Serbia

$$
\text { e-mail: melingzezelj@gmail.com }
$$

\section{SUMMARY}

It was confirmed, that the results of experimental investigations, conducted at highly saline anizotropical soils of Mesopotamian valley, including the equivalent one in Vojvodina and Kosovo ("Slatine"), determined and defined the basic concept and methods of Land Reclamation Process.

The following common classification of halomorphic soils of arid and semi-arid regions were introduced: Class of saline soils (Solončak), class of alkaline soils (Solonec) and class of dealkaline soils (Solođ).

Nominated and analysed locations in Vojvodina are denoted as the "areas of completive amelioration-Land Reclamation", spread in the vicinity of natural and artificial water resources (the rivers of Danube, Sava, Tisa and DTD Channels System).

The basic method and technological procedures of Land Reclamation of "Slatine" were applied at 3 locations in Vojvodina, covering all three holomorphic classes of soils: Solončak (Banat), Solonjec (Bačka), Solođ (Srem).

4 stages of Land Reclamation-desalinization were established: Stage I (preparation and organization of experimental plots, prior to initial salt leaching), Stage II (mechanical land preparation for salt leaching, including sets of designed technological operations), Stage III (initial salt leaching), Stage IV (reclamation crop production).

The study sublimated a part of the experimental investigations done by the author in the south-east Mesopotamia (yrs.1985, 2001, 2007).

Key words: anizotropical soils, desalination, alkalization, holomorphic soils, salt leaching. 


\section{INTRODUCTION}

The achieved experimental results initiate the fact that the application of the confirmed and in practice adopted and verified concept of land Reclamation of saline soils can transfer a considerable holomorphic soils of Serbia into the "normal", in order to provide the significant and highly productive, permanent, and stable financial and economical country potential.

It was confirmed, that the researching results performed at anizotropical highly saline multi-layer soils, with the identical forming conditions, texture and structure properties, can be equally used for amelioration and desalinization of "slatine" in Serbia. The main reason lies in identical original conditions of ours and in the region where the basic examinations were performed (Mesopotamian valley).

In addition to the proper organization of experimental fields, the complete technological procedures and instructions have been specified, representing the material basis for the further researchers in sense of collecting the dates and results in order to verify accepted methods and procedures as well as the concept of Land Reclamation in whole.

In the study the common-general classification of all holomorphic soils of arid and semi-arid regions in the world were adopted: Class of saline soils-Solončak, class of alkaline soils-Solonec and class of dealkaline soils-Solođ.

Nominated and analysed locations in region of Vojvodina, denoted as an "areas of complex amelioration-Land Reclamation", spread in the vicinity of natural and artificial water resources (rivers of Danube, Sava, Tisa and DTD Channels System), will accept experimental results and technological measures and procedures of Land Reclamation process. It is important to distinguish, that the pedogenetic processes and forming of our soils, comparing to the soils where basic experimental investigations took place, are rather similar.

The basic concept, methods and technological procedures of Reclamation of "Slatine" are applied at 3 locations in Vojvodina, embracing all three selected halomorphic soil classes. The chosen locations are representative from the aspect of required inputs. The following locations are selected: Solončak (Banat), Solonjec (Bačka) and Solod (Srem).

The study incorporated and presented a part of the experimental examination

results conducted in the region of South - East Mesopotamia in the course of 3 different periods (yrs. 1985, 2001 and 2007)

\section{MATERIALS AND METHODS}

In the first place, to adopt common classification of all Halomorphic soils of arid and semi-arid climatic (Helley, 1937, Christianser, 1947):

- Class of saline soils (in Vojvodina-Solončak),

- Class of alkaline soils (in Vojvodina-Solonec),

- Class of dealkaline soils (in Vojvodina-Solođ). 
The basic concept, methods and technological procedures of Reclamation of "Slatine" are applied at 3 locations in Vojvodina, embracing all three selected halomorphic soil classes. The chosen locations are representative from the aspect of required inputs. The following locations are selected: Solončak (Banat), Solonjec (Bačka) and Solođ (Srem).

The volume and kind of land Reclamation methods and procedures are stipulated by the initial soil salinity type and degree, including soil alkalization extension through the soil profile (Dieleman, 1973.). Therefore the volume and applied measures are variable, due to different salinity and alkalinity classes, dominantly expressed at Solončak and Solonjec, less when Solod is concerned. In all three particular cases a complexive measures of desalinization-reclamation were applied.

Within the above mentioned selected locations, it was important to provide the following conditions and procedures, works and activities organization, prior to realization of initial soli salt leaching:

- Viciniy of natural or artificial water resources for initial soil salt leaching.

- The choice of equal and uniform experimental plots dimensions.

- The experimental plots dimension depends on the distance between open collector drains of 300-400 m.

- Possibility of water evacuation from protected area (lake, accumulation with pumping station, etc.).

- The minimal experimental plot area of $20 \mathrm{ha}$ (total $60 \mathrm{ha}$ ).

- The plot unit area can provide conditions for field drainage system installation.

- Optimal conditions for leaching-irrigation field infrastructures placement (efficient connection between water intakes and hydrants positions).

- Since the initial salt leaching is realized by flooding from cassettes-checks, formed between two field drains (60 an $75 \mathrm{~m}$ spacing), it is important to place distributor pipe feeder at the highest topographic position providing uniform water release into the checks.

- To provide certain conditions for land preparation for salt leaching (Beltron, 1978).

- Piezometers nets installation for ground water oscillation registrations.

- Defending the places for opening of deep, medium and shallow pedological profiles and shallow Auger hols, where soil samples will be taken.

- To provide nearness of referent- stable meteorological station.

- Placement of field climatologic-meteorological portable station.

- It is necessary to provide the required basis for preparation of certain levels of designs. It is recommended to choose such plots having required infrastructures for reclamation measures realization, such as:

a. Pedological and hydro-pedological basin and ground works (Ćirić, 1991).

b. Geodetically basis.

c. Agricultural basis.

d. Field drainage system designs (if not available).

e. Irrigation designs (if not available).

Herewith the following stages of completive amelioration-reclamation of "Slatine"based on recent experimental results in the world, particularly the results given by the author 
(Žeželj, 2013), sublimed and presented by fundamental technical-technological Concept of land Reclamation:

- Stage I of land Reclamation (procedures and activities of experimental plots organization for initial salt leaching execution).

- Stage II of Land Reclamation (Mechanical soil preparation including the field infrastructure for salt leaching).

- Stage III of and Reclamation (Initial salt leaching).

- Stage IV of Land Reclamation (Reclamation production).

For elaboration of Land Reclamation implementation concept, the detail work execution schedule including the reclamation treatments of all four stages were designed and herewith presented:

Stage I-the chosen experimental plots at all 3 locations should have the identical shape and dimensions with existing or newly designed field leaching-irrigation infrastructures fulfilling the following criteria:

- Plot area not less than 20 ha.

- Existence of field-pipe drainage with the uniform drain spacing within the plot units.

- Elevation at the upper plot side where irrigation feeders and tube manifolds are installed must be settled at the highest point, providing the general leaching units slope at downstream direction (Alison, 1956).

- Initial salt leaching of drainage leaching units would be realized by check flooding.

- The length and width of leaching units correlates with the spacing between earth irrigation canal or pipe, upstream and collector drainage canal, downstream. This spacing in Vojvodina is mostly $200-400 \mathrm{~m}$.

- To provide connection of lateral distributor canal (over the gates) or irrigation pipeline (using hydrants, or stationary systems).

Within the experimental plots and selected leaching units the following activities were designed:

a. Finding the representative point (upper half of the experimental field), for placement and opening of 1 deep ecological profile up to $200 \mathrm{~cm}$.

b. Placement and opening of 4 medium deep profiles up to $150 \mathrm{~cm}$ ( 2 by 2 at upper part of the plot).

c. Placement and opening of 4 shallow pedological profile up to $100 \mathrm{~cm}$ depth (location as under b.).

d. At the first half of the plot along the irrigation canal-pipe, to settling the place for digging of 33 shallow hols up to $60 \mathrm{~cm}$, at each cassette line 4. At one of the central cassette-check, at each angle 1 hole should be dug (total 4). The same location where 1 deep profile is opened.

e. At the position of central cassettes, 6 piezometers should be placed.

Stage II -Very important stage within the entire Land Reclamation process is Mechanical Reclamation-Soil Preparation. The following technological operations are introduced:

- Ameliorative sub soiling from 40 to $60 \mathrm{~cm}$ depth, rarely deep ploughing parallel to filed drains direction. 
- Disk harrowing in both directions.

- Fine land levelling with agriculture land levellers (size grain of Pease).

- Construction of embankments 40 to $60 \mathrm{~cm}$ height and cassettes-shacks for leaching the salts forming. The strip of 4-6 m width above the field drains axle should be left.

- Lateral, longitudinal pipes of certain diameters at highest position, will be installed. From the both pipe sides, the water should be released towards the cassettes. At the experimental fields organized by the author, earth distributaries were used.

Stage III -At this place, it is important to verify that the experimental units are classified within the 3 classes, due to the salinity content up to $1 \mathrm{~m}$ of soil profile depth:

a. Class I-soils requiring a small volume of reclamation measures, where ECo < $4 \mathrm{mmhos} / \mathrm{cm}$.

b. Class II-soils requiring a medium volume of reclamtion measures, where 20 $<\mathrm{EC}_{\mathrm{o}}<40 \mathrm{mmhos} / \mathrm{cm}$.

c. Class III-soils requiring big volume of reclamtion measures, where $\mathrm{EC}_{\mathrm{o}}>40$ mmhos/cm.

The leaching efficiency, designed dynamic and schedule are in great extent influenced by the above two stages of Land Reclamation. The following technological operations and procedures are implemented:

1. At the prepared experimental plots areas, the first leaching rate of $25 \mathrm{~cm}$ net or $30 \mathrm{~cm}$ gross in accordance to the operational plane (during the summer period ), were applied. The first leaching rate is divided into two norms (15 and $10 \mathrm{~cm}$ net, or 18 and 12 gross), while in the original investigations $30 \mathrm{~cm}$ net and 38 gross. Presented difference covers $8 \mathrm{~cm}$ higher ET loses. The interval between two applications was 5-10 days, registered by the relative calumniation of leaching water by deep percolation from the check surface.

2. After the realization of the first leaching application rate at the entire area, the verification of the leaching effects took place, by taking the soil samples and salinity control in order to confirm achieved leaching criteria, i.e. $<4$ $\mathrm{mmhos} / \mathrm{cm}$. If the required salinity level is attended the classification into I class soil, where the next,-IV, the reclamation crop production continue.

3. Releasing of the next leaching rate $(17 \mathrm{~cm}$ net or $20 \mathrm{~cm}$ gross $)$, applied at the areas, after the first leaching rate, classified as salinity classes II and III.

4. The second leaching efficiency verification in series,-classification in class II and III. At the areas classified as class II, the reclamation crop production will be introduced.

5. After the mentioned application, dismantling of cassettes embankments and fine land levelling operation of soils class III, where the leaching process will continue.

6. At the all leaching units classified as salinity class III , the ploughing to 15 $\mathrm{cm}$ depth in order to increase the soil infiltration capacity, will take place.

7. Second embankments and cassettes digging-construction.

8. Application of the third leaching norm of $25 \mathrm{~cm}$ water depth (30 cm gross), in the areas covered by salinity class III. 
9. The third leaching efficiency verification, by taking the soil samples at the entire areas classified as salinity class III.

Stage IV-after the completion of all the categories-classes in accordance to the soil salinity degree, the reclamation crop production is ready to be introduced, by the execution of the following operations and activities, such as:

1. Disintegration and soil planning of all longitudinal and cross earth embankments (cassettes as well as protection ditches left-right from field drains axels).

2. Land levelling with agriculture leveller at the entire area.

3. Ploughing 20-25 cm dept.

4. Disk harrowing with heavy disc plates in both directions.

5. Fine land levelling.

6. Pre sowing soil preparation including the pre plant irrigation (conditionally, depends on the irrigation water availability.

7. Application of NPK fertilizer, before ploughing (2/3PK and $1 / 2 \mathrm{~N})$ and the rest of before disc harrowing.

During the reclamation crop production, the irrigation ought to be realized with the adequate equipment and machines, depending on the kind of crop cultivated. Having in mind the shape and dimensions of experimental plots, the sprinkler irrigation by use of self-driving automatically machines will be dominantly applied.

8. The sowing of the selected reclamation production crops tolerant to high soil salt content.

Besides Barley, Sweet and Red clover, the examination the possibilities of Sudan grass seeds production, managed by our scientific Institutes.

9. Irrigation with so called "additional water quantities" of 40-50 mm monthly rate (in addition to the regular and estimated monthly consumptive use). The main task of this water amount is leaching process continuation and maintenance of the obtained salinity level.

10. Harvesting and cutting the grass swaths, optionally with legumes green mass ploughing for organic matter increasing.

11. Depending on the water availability:

a. Fallow, or

b. Salt leaching during the reclamation plant production.

12. Salinity control at the whole investigated areas of all soil classes and their transfer to the Regular Agriculture Production.

\section{RESULTS AND DISCUSSION}

It is important to distinguish, that the pedogenetic processes and forming of our soils, comparing to the soils where basic experimental investigations took place, are rather similar.

The basic concept, methods and technological procedures of Reclamation of "Slatine" are applied at 3 locations in Vojvodina, embracing all three selected 
holomorphic soil classes. The chosen locations are representative from the aspect of required inputs. The following locations are selected: Solončak (Banat), Solonjec (Bačka) and Solod (Srem).

The study incorporated and presented a part of the experimental examination results conducted in the region of South - East Mesopotamia in the course of 3 different periods (yrs. 1985, 2001 and 2007)

Based on the soil salinity classes, the following Land Reclamation dynamics, i.e. time scheduling was adopted (FAO, 1973). :

1. Class I (EC<20 mmhos/cm): Leaching commences in month of October, Initial salt leaching (lasting 45-50 days),

Reclamation plant production including the additional leaching water quantities (lasting 23 months).

2. Class II $(20<\mathrm{EC}<40 \mathrm{mmhos} / \mathrm{cm})$ : Leaching starts in October month,

- $\quad$ Initial salt leaching (lasting 90 days), quantities (lasting 19,5 months),

From the mid of April to the end of September (during the second year) and then optionally setting the entire area under the fallow, or under regular irrigation (if enough water during the summer time is available).

3. Class III $(\mathrm{EC}>40 \mathrm{mmhos} / \mathrm{cm})$ :

- $\quad$ Initial salt leaching (lasts 125 days),

- $\quad$ Reclamation crop production (lasting 19, 5 months).

For the climatic conditions of Vojvodina the following Land Reclamation dynamics and time scheduling are introduced:

Salinity Class I: Depending on seasonal climatic conditions, the salt leaching starts from 15 March to 1 of April, using the following technology:

Initial salt leaching in two applications $(20 \mathrm{~cm}$ and $10 \mathrm{~cm}$ gross water depth), with 7 days interval at the whole area of all salinity classes,

Taking the soil samples in order to verify initial salt leaching process efficiency and then soil classification in II and III, and introducing the reclamation production all over the I class soils.

Reclamation plant production using vegetative as well as additional leaching water requirements lasting up to end of October month (808.5 months).

Land conservation by fallow, from October of current production year to the beginning of April next year (4-4.5 months).

At the end of March and begging of April second year, preparation for sowing and sowing of the reclamation production crops using the regular and additional irrigation-leaching up to the end of September the same year (6-6.5 months).

Salinity Class II: The salt leaching schedule the same as I class. In addition, after the first leaching rate (in two application and 7 days interval, the commencement of second leaching amount of $20 \mathrm{~cm}$ gross water depth, applied at the areas covered by class II and III. The intervals between first and second and then the third and fourth leaching application rate depends on the above anticipated technological measures and operations (soil sampling and salinity control, described mechanical reclamation measures for III class soil preparation.). The required time planned for execution ought to be pp.20 days, after the second leaching rate application. 
Reclamation crop production time schedule, the same as under Class I.

Salinity class III: Third leaching rate application of $30 \mathrm{~cm}$ gross water depth in two particular norms per $15 \mathrm{~cm}$ each $\left(4^{\text {th }}\right.$ and $5^{\text {th }}$ rates). The interval between applications is no longer than 7 days.

Reclamation crop production time schedule the same under classes I and II.

The General Land reclamation Scheme that can be applied to Vojvodina and Kosovo Slatine is given below.

Scheme1. Land reclamatiom of halomorphic soils general sheme

\begin{tabular}{|c|c|}
\hline \multirow{2}{*}{$\begin{array}{l}\text { Soil } \\
\text { Salinity } \\
\text { Class }\end{array}$} & I year of reclamation \\
\hline & $\begin{array}{l}\text { III IV V VI VII VIII IX X XI I III III IV V VI VII VIII IX X XI } \\
\text { XII I II I }\end{array}$ \\
\hline $\begin{array}{l}\text { Class I } \\
\text { Class II } \\
\text { Class } \\
\text { III }\end{array}$ & 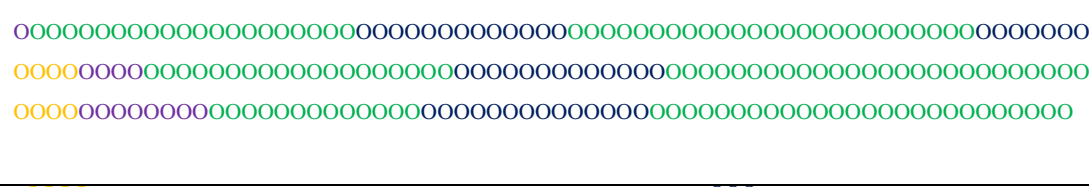 \\
\hline Legend: & $\begin{array}{l}\text { O000 Mechanical Reclamation } \\
{ }^{\mathrm{OOOOO}} \text { Initial Salt Leaching } \\
{ }^{\mathrm{O}} \text { Reclamation production }\end{array}$ \\
\hline
\end{tabular}

\section{CONCLUSION}

1. By the stydy, the stages of Land Reclamation-desaliizaion of higly saline soilsSlatine, establised at the basis of world's experimtal exeminations, sublimied and defined by the concept of land Reclamtion technology were notified as: Stage I-procedurs, measures and activities for initial soil salt leaching process preparation, Stage IImechanical land preparation, Stage III- initial soil salt leaching, Stage IV-reclamation crop production.

2. For elaboration of Land Reclamation concept execution, the general scheme and time schedule related to differnt reclamation works and treatments were emphasised.

3. The volume and dinamic of Land Reclamation process are influenced by the salinity classes specified as: Class I $(\mathrm{ECo}<4 \mathrm{mmhos} / \mathrm{cm})$, Class II $(20<\mathrm{ECo}<40$ $\mathrm{mmhos} / \mathrm{cm})$, Class III (ECo> $40 \mathrm{mmhos} / \mathrm{cm}$.

4. 4 stages of Land Reclamation-desalinization were established: Stage I (preparation and organization of experimental plots, prior to initial salt leaching), Stage II (mechanical land preparation for salt leaching, including sets of designed technological operations), Stage III (initial salt leaching), Stage IV (reclamation crop production).

5. The biggest volume of reclamation measures and treatments were applied at Solončak and than to Solonec and Solođ.

6. It was confirmed that the results of experimental research conducted at highly saline anizotropical soils of Mesopotamian valley, comparing to the equivalent one in 
Vojvodina ("Slatine"), determinate the basic concept and methods of Land Reclamation Process.

7. Taking into consideration the fact that the lands covered by the "Slatine", (property of Republic of Serbia), might provide enormous agriculture potential, and requires a serious, mutual Government, scientific Institutes and faculties, tasks towards the adequate commencement of Land Reclamation works execution.

\section{LITERATURE}

[1] Alison, L.E.(1956).: Soil and plant responses to VAMA and HPAN soil conditiners in the presence of high exchangeable sodium. Soil.sci.of Amer.proceed.vol. 20, No. 2, USA.

[2] Beltron, J.J.(1978.): Drainage and reclamation of Salr affected Soils of Rardenas area. International Institute for Land reclamation, Wageningen, Holland.

[3] Ćirić, M.(1991): Pedologija, Svijetlost, Sarajevo.BiH

[4] Dieleman, P.J.(1973): Reclamatio of salt effected soils in Iraq . Internat. Inst.for Land reclamation and Improvement, Wageningen, 175p, Holland.

[5] Christianser, J.E.(1947): Some permeability Characterististics of Saline and Alkali Soils. Agr.Eng.,Vol.28., USA.

[6] FAO, (1973).: Drainage of Salty Soils. Paper N ${ }^{0} 16$, Rome, Italy.

[7] 7. Kelley, W.P.(1937): The Reclamation of Alkali SoilsCalif.Agr.Exp.StaBul.617, USA.

[8] FAO/UNESCO, (1973)- Irrigation, Drainage and Salinity. An International Source book, Hutchinson, Roma, Italy.

[9] Žeželj, B.(2013.): Metode kompleksnih melioracija zasoljenih zemljista aridnih I semi-aridnih reiona, sa aplokacijom na ekvivalentna zemljišta i uslove Srbije. Ph. disertation, Faculty of Biofarming, Megatrend Univ.,Bačka Topla, Serbia.

\section{KOMPARATIVNA ANALIZA KRITERIJUMA KOMPLEKSNIH MELIORACIJA ANIZOTROPNIH-HALOMORFNIH ZEMLJIŠTA}

\section{Branislav Žeželj, Stanislav Glumac, Zdravko Hojka}

\section{ABSTRAKT}

Utvrđeno je, da su rezultati eksperimentalnih iatraživanja sprovedeni na zaslanjenim anizotropnim zemljišima Mesopotamijske ravnice, uključujući ekvivalentna zemljišta Vojvodine i Kosova ("Slatine", površine oko 300.000 ha), odredili i definisali osnovni koncept i metode postupka reklamacije - desalinizacije zemljišta (kompleksne melioracije zemljišta).

Ustanovljena je sledeća opšta-zajednička klasifikacija halomorfnih zemljišta aridnih i semi aridnig regiona : Klasa zaslanjenih zemljništa (Solončak), klasa alkalizovanog zemljišta (Solonac) i klasa dealkalizovanog zemljišta (Solođ).

Analizirane su i usvojene lokacije u Vojvodini, označene kao "područja kompleksnih melioracija SLATINA", rasprostranjene uz prirodne i veštačke vodotoke (Sava, Dunav, Tisa, sistem DTD, te neke od veštačkih akomulacija u Sremu), na kojima ce biti 
primenjeni rezultati istraživanja u pravcu definisanja vrste i obima mera i tehnoloških postupaka reklamacije zaslonjenih zemljišta.

Utvrđene su 4 faze reklamacije-desalinizacije zemljišta i to: I Faza ( priprema i organizovanje oglednih jedinica pre inicijalnog ispiranja soli iz zemljišta), II faza (mehanička priprema zemljišta za in icijalno ispiranje, uključujući set projektovanih tehnoloških operacija), III faza (inicijalno ispiranje soli iz zemljišta) i IV faza (faza prelazne-reklamativne biljne proizvodnje).

Studija je sublimirala i prikazala deo rezultata eksperimentalnih istraživanja koje je autor sproveo na području Jugo-Istočne Mesopotamije u nekoliko navrata u periodu: 1985, 2001 i 2007 godine.

Ključne reči: anizotropna zemljišta, desalinizacija, alkalizacija, halomorfna zemljišta, ispiranje soli.

Primljeno: 11. 05. 2015. god.

Prihvaćeno: 18. 05. 2015. god. 